\title{
ТОВАРОЗНАВЧИЙ АНАЛІЗ РИНКУ ПОЛЬЩІ ЗАСОБІВ ДЛЯ ВИМІРЮВАННЯ АРТЕРІАЛЬНОГО ТИСКУ
}

\author{
Ю. А. Равлів, В. Р. Max \\ Тернопільський національний медичний університет \\ імені І. Я. Горбачевського МОз Украӥни
}

\begin{abstract}
Гіпертонічна хвороба - це захворювання серцево-судинної системи, яке проявляється систематичним підвищенням артеріального тиску. Своєчасне виявлення артеріальної гіпертензії, проведення заходів первинної та вторинної профілактики та призначення адекватної медикаментозної терапії затримує прогресування захворювання, знижує ризик виникнення ускладнень, сприяє поліпшенню якості життя та збереженню працездатності. Актуальним є дослідження фармацевтичного ринку щодо засобів вимірювання артеріального тиску для своєчасної діагностики артеріальної гіпертензії.
\end{abstract}

\section{TRADE ANALYSIS OF DIFFERENT DEVICES FOR BLOOD PRESSURE MONITORING IN POLAND}

\author{
Yu. A. Ravliv, V. R. Mach \\ I. Horbachevsky Ternopil National Medical University
}

Hypertension is a disease of cardiovascular system, which is manifested by a systematic increase of blood pressure. Timely detection of hypertension, primary and secondary prevention and adequate therapy delay the progression of the disease, reduce all the risks of complications, contribute to improving of the quality of life and maintain working capacity. The pharmaceutical market research according to different devices for blood pressure monitoring for timely diagnosis of hypertension remains pertinent.

Вступ. На сьогодні контроль рівня артеріального тиску має велике значення, адже серцево-судинні захворювання вже тривалий час залишаються лідерами серед причин смерті, вони впевнено витісняють із цієї позиції інфекційні хвороби [3]. Найпоширенішими серед серцево-судинних захворювань $\epsilon$ артеріальна гіпертензія. Згідно з даними ВОО3, за 2019 р. гіпертонічна хвороба серця, основним проявом якої $\epsilon$ артеріальна гіпертензія, входить у десятку причин смерті населення нашої планети [1]. За оцінками ВООЗ, 17,5 млн осіб щороку помирають від інфаркту міокарда та інсульту, однак переконливі наукові дані показують, що до 80 \% таких смертей можна уникнути. Для визначення і контролю артеріального тиску використовують тонометри, асортимент яких на ринку є значним.

За сучасними уявленнями ідеальний тонометр має з точністю вимірювати артеріальний тиск, саме точність показників $є$ ключовим критерієм вибору (С Ю. А. Равлів, В. Р. Мax, 2020 тонометра. Крім того, вони повинні бути зручними та надійними у використанні [2].

На даному етапі підвищення профілактичних заходів у зв'язку із розповсюдженням різних серцевосудинних захворювань призводить до вивчення ринку засобів для контролю артеріального тиску для забезпечення вчасного виявлення патології або для правильного лікування вже наявного захворювання. Отже, актуальним для медичної сестри $\epsilon$ вивчення ринку даної групи товарів [3].

Основна частина. Для досягнення поставленої мети проведено товарознавчий аналіз польського ринку засобів для вимірювання артеріального тиску. Польський ринок в основному забезпечений такими видами тонометрів: механічні, автоматичні, тонометри на зап'ястя. Механічні тонометри в найбільшій кількості постачають з Нідерландів, що займає 50 \% ринку, Швейцарії - 25 \% і власне Польщі - 25 \% (рис. 1). 


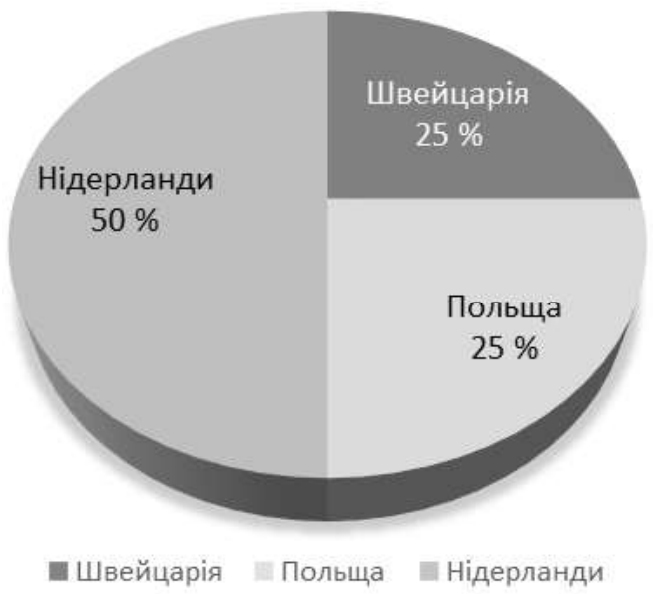

PUC. 1. Країни-виробники механічних тонометрів.

Автоматичні тонометри представлені різними країнами-виробниками. Найбільшу частину ринку займає Польща - 32 \%, Швейцарія - 24\%, Японія - 22 \%, Німеччина - $17 \%$, Італія - 2 \% і Китай - 2 \% (рис. 2).

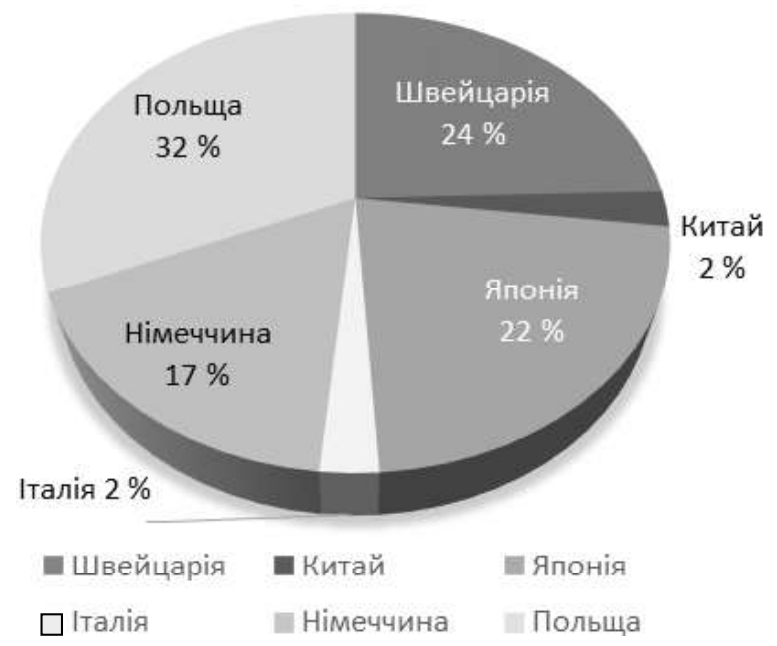

Puc. 2. Країни-виробники автоматичних тонометрів.

\section{СПИСОК ЛІТЕРАТУРИ}

1. Kawecka-Jaszcz K. Rozpowszechnienie nadciśnienia tętniczego w zależności od płci w świetle badań epidemiologicznych w Polsce / Kalina Kawecka-Jaszcz, Aneta Pośnik-Urbańska, Piotr Jankowski. 1-6.

2. (2016) An Expert Opinion from the European Society of Hypertension European Union Geriatric Medicine Society Working Group on the Management of Hypertension in Very
Тонометри на зап'ястя постачають: 50 \% - 3 Німеччини, 25 \% - зі Швейцарії і 25 \% виготовляє власне Польща (рис. 3).

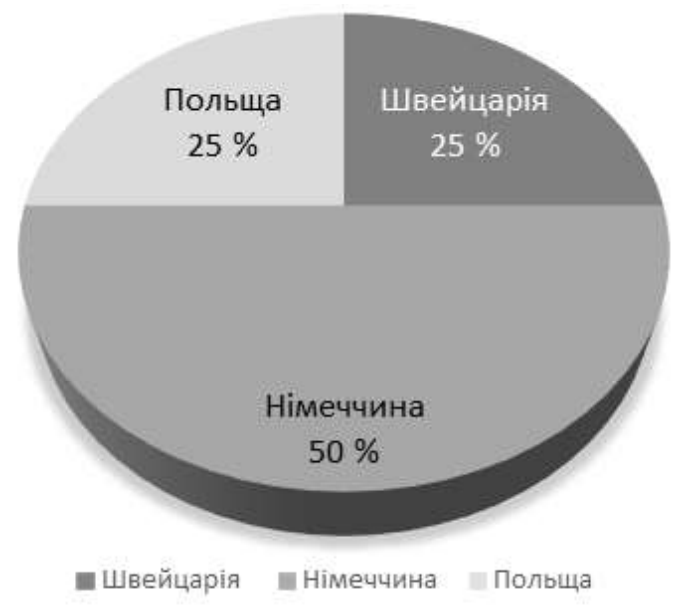

Рис. 3. Країни-виробники тонометрів на зап'ястя.

Висновки. Встановлено країни-постачальники засобів для вимірювання артеріального тиску. 3 Нідерландів до Польщі найбільше надходить механічних тонометрів, з Німеччини - тонометрів на зап'ястя, найбільшу частину автоматичних тонометрів, наявних на ринку Польщі, виготовляють саме у Польщі.

Old, Frail Subjects / A. Benetos, C. J. Bulpitt, M. Petrovic [et al.] Hypertension. - Vol. 67 (5). - P. 820-825.

3. A Randomized Trial of Intensive versus Standard BloodPressure Control / SPRINT Research Group, J. T. Jr. Wright, J. D. Williamson [et al.] // N. Engl. J. Med. - 2015. Vol. 373 (22). - P. 2103-2116. 